Objective: To present in detail the diagnosis of solitary pulmonary nodule and especially evaluation of:

- clinical data

- analysis of radiological images,

- selected laboratory tests.

Material and methods: There were 50 patients -31 men and 19 women at the mean age $58.7 \pm 11.4$ years old who underwent surgical treatment because of a solitary pulmonary nodule. Interview, physical examination, computed tomography, bronchoscopy, spirometry, and laboratory tests needed for the operation were performed in all these patients. Additionally LDH, fibrinogen, ESR, and the tumour markers CEA, Ca 15-3, Ca 19-9, NSE, SCC, and Cyfra 21-1 were measured from the blood sample collected during admission.

Results: Malignant tumour was diagnosed in 24 patients, benign in 26. There is a significant difference between patients with malignant and nonmalignant tumours in age ( 54.46 years vs. 63.33 years), size of the tumour in the lung scan of chest CT $(1.53 \mathrm{~cm}$ vs. $1.91 \mathrm{~cm}$ ) and location (lower right lobe vs. upper right lobe). There is no significant difference between type of tumour and sex, clinical symptoms and laboratory tests.

Conclusions:

1. The risk factors of malignancy in patient with solitary pulmonary nodule are:

- age $\geq 56.5$ years,

- size of the tumour in the lung scan of chest $C T \geq 1.45 \mathrm{~cm}$,

- location in upper right lobe.

2. LDH, fibrinogen, ESR, and the tumour markers CEA, Ca 15-3, Ca 19-9, NSE, SCC, and Cyfra 21-1 are not useful in differential diagnosis of solitary pulmonary nodule.

Key words: solitary pulmonary nodule, differential diagnosis, lung cancer.

\section{Differential diagnosis of a solitary pulmonary nodule of the lung on the grounds of selected laboratory tests and radiological examination}

\author{
Diagnostyka różnicowa pojedynczego cienia okrąłego płuca \\ na podstawie wybranych parametrów badań laboratoryjnych \\ i obrazowych
}

Aleksandra Szlachcińska, Józef Kozak

Oddział Kliniczny Chirurgii Klatki Piersiowej i Rehabilitacji Oddechowej, WSS im. M. Kopernika w Łodzi

\section{Wstęp}

Pojedynczy cień okrągły płuca (PCOP) jest pojęciem radiologicznym. Definiuje się go jako widoczny na radiogramie klatki piersiowej lub w badaniu tomografii komputerowej klatki piersiowej okrągły lub owalny cień bez niedodmy i rozstrzeni oskrzeli w otaczającym miąższu płucnym. Zmianie tej nie towarzyszy powiększenie węzłów chłonnych śródpiersia ani obecność płynu w jamie opłucnowej [1-3]. Większość autorów definiuje PCOP jako zmianę wielkości do $3 \mathrm{~cm}$, określając większą zmianę jako masę [3]. Pojedynczy cień okrągły płuca stwierdza się na 0,09-0,2\% [5] radiogramów klatki piersiowej. Około 90\% z nich to przypadkowe znaleziska [2]. Dzięki powszechnemu wykorzystywaniu w medycynie tomografii komputerowej liczba nowo wykrywanych PCOP stale wzrasta [6].

Radiologiczny obraz PCOP wymaga szerokiej diagnostyki różnicowej pośród kilkudziesięciu jednostek chorobowych. Obejmuje ona zmiany nowotworowe i nienowotworowe (zapalne, niezapalne, pasożytnicze, wrodzone, pourazowe i inne) $[3,4]$. Przeprowadzana diagnostyka PCOP ma na celu wczesne wdrożenie odpowiedniego leczenia. Dotyczy to szczególnie zmian nowotworowych o charakterze złośliwym, a szczególnie pierwotnego raka płuca we wczesnym stopniu zaawansowania. Rak płuca jest wiodącą przyczyną zgonów z powodu nowotworów zarówno wśród mężczyzn, jak i kobiet. Wczesne wykrycie i leczenie raka płuca zwiększa szansę na skuteczne leczenie oraz zmniejsza śmiertelność [7]. Średnie 5-letnie przeżycie u chorych na raka płuca wynosi 10-15\% [8]. Najlepsze rokowanie występuje u chorych operowanych w I stopniu zaawansowania choroby, a szczególnie w stopniu IA (T1NOMO). W tym stopniu zaawansowania 5-letnie przeżycia sięgają ok. 70\%. [5]. Cecha T1 oznacza zmianę wielkości do $3 \mathrm{~cm}$ otoczoną tkanką płucną lub opłucną płucną, bez naciekania oskrzela głównego. Spełnia więc ona kryteria definicji cienia okrągłego.

Celem pracy jest ocena przydatności:

- danych klinicznych,

- szczegółowej analizy badań obrazowych,

- wybranych parametrów badań laboratoryjnych w diagnostyce różnicowej u chorych z PCOP.

\section{Materiat i metody}

Badania przeprowadzono na Oddziale Klinicznym Chirurgii Klatki Piersiowej i Rehabilitacji Oddechowej Wojewódzkiego Szpitala Specjalistycznego 
Cel pracy: Kompleksowe opracowanie zagadnienia diagnostyki pojedynczego cienia okrągłego płuca, a w szczególności ocena przydatności:

- danych klinicznych,

- analizy badań obrazowych,

- wybranych parametrów badań laboratoryjnych.

Materiał i metody: Grupę badaną stanowiło 50 pacjentów - 31 mężczyzn i 19 kobiet w wieku średnio 58,7 $\pm 11,4$ roku, leczonych operacyjnie z powodu pojedynczego cienia okrągłego płuca. U wszystkich przeprowadzano badanie podmiotowe, przedmiotowe, wykonano tomografię klatki piersiowej, bronchoskopię, spirometrię, badania laboratoryjne niezbędne do przeprowadzenia zabiegu chirurgicznego. Zakres badań laboratoryjnych poszerzono o ocenę stężeń LDH, fibrynogenu, markerów nowotworowych - CEA, Ca 15-3, Ca 19-9, NSE, SCC, Cyfra 21-1 oraz OB. Parametry te oznaczano z próbki krwi pobranej przy przyjęciu na oddział.

Wyniki: Obecność zmiany złośliwej stwierdzono u 24 chorych, łagodnej u 26. Istotne statystycznie różnice pomiędzy chorymi ze zmianą łagodną i złośliwą stwierdzono: w wieku $(54,46$ vs 63,33 roku), wielkości cienia ocenianej na skanie płucnym tomografii klatki piersiowej $(1,53 \mathrm{vs} 1,91 \mathrm{~cm})$ oraz lokalizacji (płat dolny prawy vs płat górny prawy). Nie stwierdzono zależności pomiędzy typem cienia okrągłego płuca a płcią, objawami klinicznymi, poziomem ocenianych parametrów laboratoryjnych.

\section{Wnioski:}

1. U chorego z cieniem okrągłym płuca ryzyko rozwoju nowotworu złośliwego zwiększa:

- wiek $\geq 56,5$ roku,

- wielkość cienia w badaniu tomografii klatki piersiowej w oknie płucnym $\geq 1,45 \mathrm{~cm}$,

- lokalizacja zmiany w płacie górnym prawym.

2. Ocena stężenia LDH, fibrynogenu, $\mathrm{OB}$ oraz wybrane markery nowotworowe nie są przydatne w różnicowaniu pojedynczych cieni okrągłych płuc.

Słowa kluczowe: pojedynczy cień okrągły płuca, diagnostyka różnicowa, rak płuca. im. M. Kopernika w Łodzi. Grupę badaną stanowiło kolejnych 50 pacjentów zakwalifikowanych do leczenia operacyjnego z powodu PCOP, u których na podstawie przeprowadzonej wcześniej diagnostyki nie udało się ustalić rozpoznania.

W badanej grupie znalazło się 31 mężczyzn (62\%) i 19 kobiet (38\%) w wieku 17-77 lat (średnio 58,7 $\pm 11,4$ roku).

U wszystkich chorych w trakcie kwalifikacji do leczenia operacyjnego wykonano tomografię komputerową klatki piersiowej, bronchoskopię oraz spirometrię. Na oddziale $u$ chorych przeprowadzano badanie podmiotowe i przedmiotowe, wykonano podstawowe badania laboratoryjne niezbędne do przeprowadzenia zabiegu chirurgicznego - morfologię krwi, koagulogram, jonogram, parametry wydolności nerek. Dodatkowo u pacjentów z PCOP zakres badań laboratoryjnych poszerzony został o ocenę stężeń LDH, fibrynogenu, markerów nowotworowych - CEA, Ca 15-3, Ca 19-9, NSE, SCC, Cyfra 21-1 oraz OB. Parametry te oznaczano z próbki krwi pobranej przy przyjęciu na oddział.

Technika zabiegu chirurgicznego polegała na wykonaniu minitorakotomii i wycięciu klinowym zmiany. Następnie na podstawie wykonanego badania śródoperacyjnego podejmowano decyzję o dalszym przebiegu operacji. W przypadku zmiany o charakterze złośliwym pierwotnej zabieg poszerzony był o wykonanie lobektomii z limfadenektomią. Ostateczne rozpoznanie ustalano po uzyskaniu wyniku badania histologicznego materiału pooperacyjnego.

Otrzymane wyniki badań poddano analizie statystycznej, wykorzystując test niezależności $\chi^{2}$ lub test U Manna-Whitneya. Ponadto przydatność zmiennych mierzalnych w diagnozowaniu nowotworów złośliwych oceniono za pomoca analizy krzywych ROC.

\section{Wyniki}

Na podstawie pooperacyjnego rozpoznania histologicznego zmianę łagodną stwierdzono u 26 pacjentów (52\%), złośliwą u 24 (48\%). W tabeli 1. przedstawiono strukturę pacjentów wg rozpoznania.

Do dalszej analizy badanych podzielono na dwie grupy:

- I - pacjenci ze zmianą o charakterze łagodnym - 26 chorych,

- II - pacjenci z nowotworem złośliwym - 24 chorych.

Table 1. Structure of patients according to diagnosis

Tabela 1. Struktura pacjentów ogółem według rozpoznania

\begin{tabular}{|lcc|}
\hline Rozpoznanie histopatologiczno-patologiczne & Liczba pacjentów & $\%$ \\
\hline odpryskowiak & 14 & 28 \\
\hline rak płaskonabłonkowy płuca & 12 & 24 \\
\hline gruczolakorak płuca & 8 & 16 \\
\hline gruźliczak & 6 & 12 \\
\hline węzeł chłonny & 1 & 2 \\
\hline zmiana zapalna & 1 & 2 \\
\hline ziarniniak & 1 & 2 \\
\hline zwapnienie & 1 & 2 \\
\hline calcyfing tumor of the pleurae & 1 & 2 \\
\hline solitary fibrous tumour & 1 & 2 \\
\hline rak wielkokomórkowy & 1 & 2 \\
\hline przerzut - tarczyca & 1 & 2 \\
\hline przerzut - nerka & 1 & 2 \\
\hline przerzut - mięsakorak & 1 & 2 \\
\hline
\end{tabular}




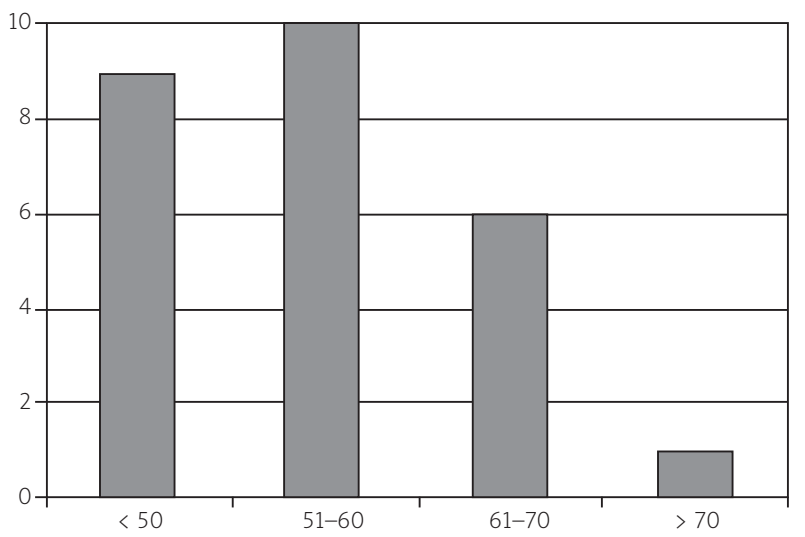

Fig. 1. Age structure of patients with benign tumour Ryc. 1. Rozkład wieku w grupie pacjentów ze zmianą łagodną

Table 2. Structure of patients according to symptomps Tabela 2. Struktura pacjentów według objawów

\begin{tabular}{|lcc|}
\hline Objawy & $\begin{array}{c}\text { Liczba pacjentów } \\
\text { ze zmianą łagodną }\end{array}$ & $\begin{array}{c}\text { Liczba pacjentów } \\
\text { z nowotworem } \\
\text { złośliwym }\end{array}$ \\
\hline brak & 19 & 17 \\
\hline duszność, osłabienie & 2 & - \\
\hline kaszel & 2 & 2 \\
\hline spadek masy ciała & 1 & - \\
\hline osłabienie, spadek masy ciała & 1 & 1 \\
\hline duszność & 1 & 2 \\
\hline zapalenie płuc & - & 1 \\
\hline krwioplucie & - & 1 \\
\hline
\end{tabular}

Table 3. Structure of patients according to location of solitary pulmonary nodule

Tabela 3. Struktura pacjentów według lokalizacji cienia okrągłego

\begin{tabular}{|lcc|}
\hline Lokalizacja zmiany & $\begin{array}{c}\text { Liczba pacjentów } \\
\text { ze zmianą tagodną }\end{array}$ & $\begin{array}{c}\text { Liczba pacjentów } \\
\text { z nowotworem } \\
\text { złośliwym }\end{array}$ \\
\hline płat górny lewy & 3 & 8 \\
\hline płat górny prawy & 6 & 10 \\
\hline płat dolny lewy & 4 & 4 \\
\hline płat dolny prawy & 10 & 2 \\
\hline szczelina międzypłatowa & 2 & - \\
\hline płat środkowy & 1 & - \\
\hline
\end{tabular}

W grupie 26 chorych ze zmianą łagodną było 13 kobiet (50\%) i 13 mężczyzn (50\%) w wieku 17-75 lat, średnio 54,26 $\pm 12,3$ roku. W grupie 24 chorych z nowotworem złośliwym było 6 kobiet (25\%) i 18 mężczyzn (75\%) w wieku 41-77 lat, średnio 63,33 $\pm 8,53$ roku. Rozkład wieku w obu grupach przedstawiono na rycinach 1. i 2. Analiza danych klinicznych

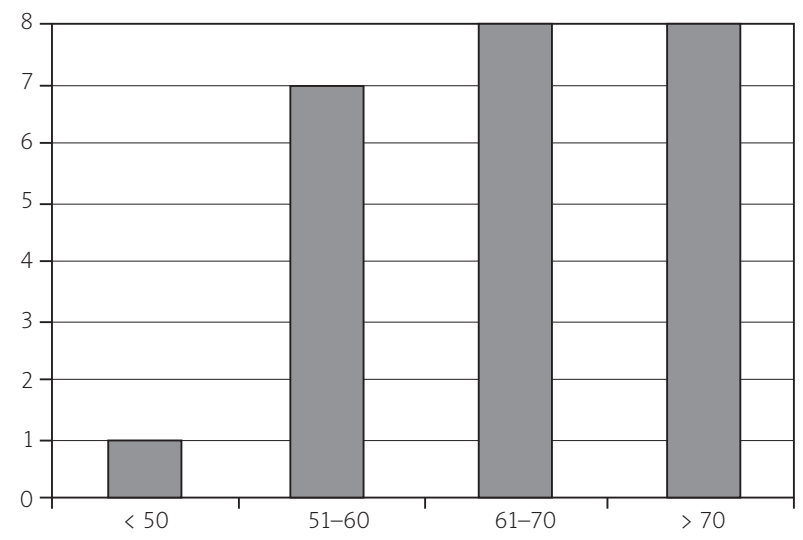

Fig. 2. Age structure of patients with malignant tumour Ryc. 2. Rozkład wieku w grupie pacjentów z nowotworem złośliwym

wskazuje, że u zdecydowanej większości chorych nie występowały żadne objawy ze strony układu oddechowego oraz objawy ogólne. U 19 z 26 pacjentów (73,08\%) ze zmianą łagodną i 17 z 24 (70,83\%) z nowotworem złośliwym nie odnotowano dolegliwości związanych z przyczyną hospitalizacji. Dane dotyczące objawów przedstawiono w tabeli 2. W obu grupach przeważali pacjenci palący papierosy (16 z 26 pacjentów ze zmianą łagodną i 18 z 24 pacjentów ze zmianą złośliwą). U pacjentów ze zmianą łagodną częściej była ona zlokalizowana po stronie prawej [18 (69,2\%)] niż lewej [8 (30,8\%)]. U pacjentów z nowotworem złośliwym równie często była umiejscowiona po stronie prawej - 12 chorych (50\%), jak po lewej - 12 chorych (50\%). Dane dotyczące lokalizacji cienia okrągłego przedstawiono w tabeli 3. Tabela 4. zawiera dane dotyczące wielkości cienia okrągłego ocenianego na podstawie badania tomograficznego klatki piersiowej na skanach płucnych (TK płuco) i śródpiersiowych (TK śródpiersie), różnicy w wielkości zmiany ocenianej w obu oknach (TK różnica), a także wielkości cienia okrągłego ocenianej w badaniu patomorfologicznym po jego wycięciu w obu grupach. Obecność spikuli w TK klatki piersiowej stwierdzono u 1 z 26 chorych z guzem łagodnym i 5 z 24 z nowotworem złośliwym. W tabeli 5. zamieszczono analizę wybranych parametrów badań laboratoryjnych, uwzględniając zakres normy badań.

Analizując obie grupy badanych, stwierdzono istotne statystycznie różnice w wieku pacjentów ze zmianą łagodną i zmianą o charakterze złośliwym (54,46 vs 63,33 roku), wielkości zmiany ocenianej na skanie płucnym tomografii klatki piersiowej $(1,53$ vs 1,91 cm) oraz wielkości w badaniu patomorfologicznym pooperacyjnym (1,33 vs 2,01 cm).

Stwierdzono istotną statystycznie $(p<0,05)$ zależność między typem nowotworu a lokalizacją pojedynczego cienia płuca. Zmiany o charakterze łagodnym najczęściej stwierdzano w płacie dolnym płuca prawego (10 chorych ze zmianą łagodną - 38,46\%), zmiany złośliwe zaś w płacie górnym płuca prawego (10 chorych ze zmianą złośliwą 41,46\%). Nie odnotowano istotnej statystycznie zależności pomiędzy typem nowotworu a płcią, występowaniem objawów klinicznych, nikotynizmem oraz poziomem ocenianych parametrów laboratoryjnych. 
Table 4. The size of the tumor in chest CT and pathomorphological examination

Tabela 4. Wielkość cienia okrągłego $\mathrm{w}$ badaniu TK i pooperacyjnym $(\mathrm{w} \mathrm{cm})$

\begin{tabular}{lcccccc} 
Zmienna & \multicolumn{3}{c}{ Zmiana łagodna } & & \multicolumn{2}{c}{ Nowotwór złośliwy } \\
\cline { 2 - 5 } & średnia & minimum & maksimum & średnia & minimum & maksimum \\
wielkość zmiany & $1,33 \pm 0,60$ & 0,50 & 3,00 & $2,01 \pm 0,94$ & 0,50 \\
TK płuco & $1,53 \pm 0,65$ & 0,50 & 3,30 & $1,91 \pm 0,60$ & 1,00 \\
TK śródpiersie & $0,80 \pm 0,83$ & 0,00 & 3,10 & $0,97 \pm 0,99$ & 0,00 \\
TK różnica & $0,74 \pm 0,44$ & 0,00 & 2,00 & $0,9 \pm 0,65$ & 3,30 & 0,00
\end{tabular}

Table 5. Selected laboratory tests in patients with solitary pulmonary nodule

Tabela 5. Wybrane parametry badań laboratoryjnych u pacjentów z pojedynczym cieniem okrągłym płuca

\begin{tabular}{|c|c|c|c|c|}
\hline \multirow[t]{2}{*}{ Zmienna } & \multicolumn{2}{|c|}{ Zmiana łagodna } & \multicolumn{2}{|c|}{ Nowotwór złośliwy } \\
\hline & średnia & $\begin{array}{c}\text { wynik w normie/ } \\
\text { powyżej normy }\end{array}$ & średnia & $\begin{array}{c}\text { wynik w normie/ } \\
\text { powyżej normy }\end{array}$ \\
\hline OB (mm/godz.) & $16,12 \pm 11,77$ & $9 / 17$ & $15,54 \pm 11,29$ & $10 / 14$ \\
\hline $\mathrm{LDH}(\mathrm{U} / \mathrm{l})$ & $175,15 \pm 29,43$ & $23 / 3$ & $169,33 \pm 36,15$ & $22 / 2$ \\
\hline fibrynogen (mg/dl) & $377,50 \pm 86,52$ & $18 / 8$ & $392,17 \pm 71,94$ & $13 / 11$ \\
\hline $\mathrm{SCC}(\mathrm{ng} / \mathrm{ml})$ & $0,97 \pm 0,88$ & $22 / 4$ & $1,49 \pm 2,81$ & $18 / 6$ \\
\hline NSE $(\mathrm{mg} / \mathrm{ml})$ & $10,98 \pm 3,17$ & $24 / 2$ & $11,80 \pm 3,59$ & $22 / 2$ \\
\hline Ca19-9 (U/ml) & $7,74 \pm 5,88$ & $26 / 0$ & $10,50 \pm 17,63$ & $23 / 1$ \\
\hline Ca15-3 (U/ml) & $19,57 \pm 8,79$ & $20 / 6$ & $17,07 \pm 5,04$ & $23 / 1$ \\
\hline CEA (ng/ml) & $2,09 \pm 1,12$ & $25 / 1$ & $6,02 \pm 8,13$ & $15 / 9$ \\
\hline Cyfra 21-1 (ng/ml) & $1,38 \pm 0,58$ & $24 / 2$ & $0,97 \pm 0,31$ & $21 / 3$ \\
\hline
\end{tabular}

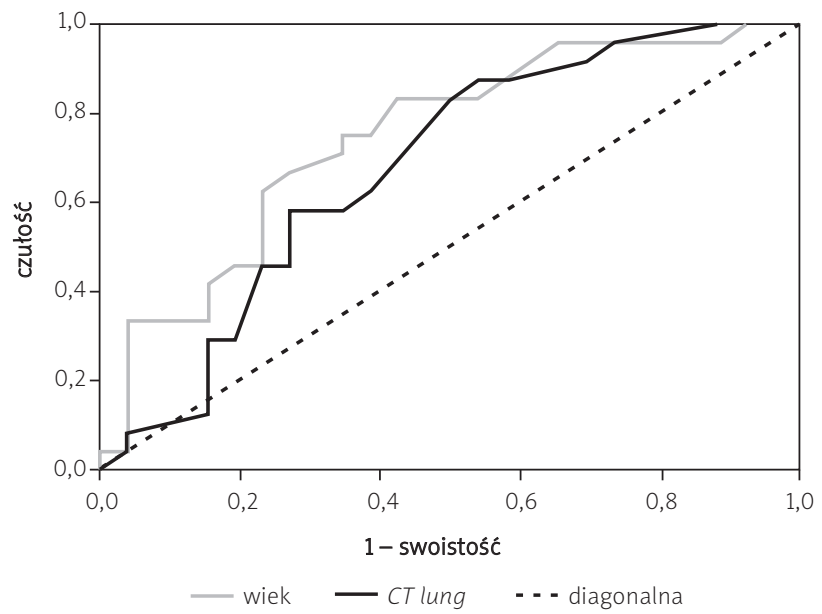

Fig. 3. ROC curves for age and size of the tumor in the lung scan of chest CT (lung CT)

Ryc. 3. Krzywe ROC dla wieku i wielkości zmiany w oknie płucnym TK (CT lung)

Na podstawie analizy krzywych ROC (ryc. 3.) znaleziono punkty odcięcia dla zmiennych mierzalnych, które istotnie wiążą się ze złym rokowaniem (nowotwór złośliwy):

- wiek $\geq 56,5$ roku.

- wielkość zmiany oceniana na skanie płucnym tomografii komputerowej (TK płuco) $\geq 1,45 \mathrm{~cm}$.
Table 6. Sensitivity, specificity, PPV, NPV for patient's age, the size of the tumor in the pathomorphological examination and the size in the lung scan of chest $C T$

Tabela 6. Czułość, swoistość, PPV, NPV dla wieku pacjentów, wielkości zmiany w badaniu patomorfologicznym pooperacyjnym oraz wielkości zmiany na skanie płucnym tomografii komputerowej (TK płuco)

\begin{tabular}{|lcccc|} 
Test diagnostyczny & $\begin{array}{c}\text { Czułość } \\
(\%)\end{array}$ & $\begin{array}{c}\text { Swoistość } \\
(\%)\end{array}$ & $\begin{array}{c}\text { PPV } \\
(\%)\end{array}$ & $\begin{array}{c}\text { NPV } \\
(\%)\end{array}$ \\
\hline wiek $\geq 56,5$ & 83,33 & 57,69 & 64,52 & 78,95 \\
\hline wielkość $\geq 1,10$ & 91,30 & 50,00 & 61,76 & 86,67 \\
\hline TK płuco $\geq 1,45$ & 83,33 & 50,00 & 60,61 & 76,47
\end{tabular}

Zmienne te wraz z wymienionymi wartościami można potraktować jako test diagnostyczny pozwalający przewidywać wystąpienie nowotworu złośliwego w przypadku PCOP.

W tabeli 6. przedstawiono czułość (odsetek pacjentów z nowotworem złośliwym, którzy zostali prawidłowo zdiagnozowani przez test), swoistość (odsetek pacjentów z nowotworem łagodnym, którzy zostali prawidłowo zidentyfikowani przez test), dodatnią wartość predykcyjną - PPV (odsetek pacjentów z pozytywnym wynikiem testu, którzy mają nowotwór złośliwy) oraz ujemną wartość predykcyjną - NPV (odsetek pacjentów z ujemnym wynikiem testu, którzy nie mają nowotworu złośliwego) dla tych parametrów. 


\section{Dyskusja}

Podstawowym celem przeprowadzanych badań u pacjentów z pojedynczym cieniem okrągłym płuca jest rozstrzygnięcie z jakiego rodzaju zmianą mamy do czynienia: łagodną czy o charakterze złośliwym, a tym samym wdrożenie odpowiednio szybko właściwego leczenia. Już w 1976 r. Ray i wsp. na podstawie materiału zgromadzonego z 20 lat obserwacji wykazali, że wczesna torakotomia u pacjentów z pojedynczym cieniem okrągłym płuca pozwala wykryć raka płuca we wczesnym stopniu zaawansowania, a rokowanie u tych pacjentów jest lepsze niż u chorych operowanych w późniejszych stadiach [10]. Od tego czasu trwają badania nad metodami diagnostycznymi umożliwiającymi z jednej strony wczesne wykrycie zmiany, a z dugiej strony ustalenie właściwego rozpoznania w celu uniknięcia niepotrzebnego w wielu wypadkach leczenia operacyjnego. Metody diagnostyczne można podzielić na: metody obrazujące pojedynczy cień okrągły płuca (tomografia klatki piersiowej), metody umożliwiające ustalenie rozpoznania histologicznego (bronchoskopia, biopsja transtorakalna), metody obrazujące biologię zmiany (scyntygrafia receptorowa, pozytonowa tomografia emisyjna, ocena wybranych parametrów laboratoryjnych, m.in. markery nowotworowe). Nie bez znaczenia jest również ocena danych z badania klinicznego. Pomimo rozwoju wielu technik diagnostycznych często nie pozwalają one na pewne ustalenie rozpoznania. Wycięcie zmiany z badaniem śródoperacyjnym nadal w wielu wypadkach pozostaje jedyną metodą diagnostyczną umożliwiającą ostateczne ustalenie rozpoznania, charakteryzującą się jednocześnie 100-procentową czułością i swoistością.

W badanej grupie chorych było prawie dwa razy więcej mężczyzn niż kobiet (31 vs 19), a w grupie chorych z nowotworem złośliwym - 3 razy więcej (18 vs 6). Choć nie stwierdzono istotnej statystycznie zależności pomiędzy płcią a wystąpieniem nowotworu złośliwego, w literaturze można odnaleźć dane potwierdzające przewagę płci męskiej wśród chorych poddawanych interwencji chirurgicznej z powodu obecności PCOP [11].

Wiek pacjentów wahał się od 17 do 77 lat. Stwierdzono, że dla wieku $\geq 56,5$ roku prawdopodobieństwo wystąpienia nowotworu złośliwego wynosi 64,52\%, a poniżej 56,5 roku prawdopodobieństwo, że pacjent ma nowotwór łagodny wynosi 78,95\%. Uzyskane dane na temat związku występowania nowotworu złośliwego z wiekiem są zgodne z dostępną literaturą [10]. Rubins i wsp. w swojej pracy stwierdzili występowanie nowotworu złośliwego u 36\% pacjentów w wieku poniżej 45 lat i 96\% w wieku powyżej 75 lat [12]. Ta zależność potwierdzana jest również w badaniach nad skriningiem raka płuca z wykorzystaniem tomografii komputerowej. W badaniach, w których była niższa granica wieku kwalifikującego do wykonania testu, stwierdzano mniejszy odsetek wykrywanego raka płuca $[13,14]$.

Rozwój techniki i coraz nowsze generacje tomografów komputerowych umożliwiają wykrywanie coraz mniejszych zmian. W badaniu tomograficznym klatki piersiowej można uwidocznić zmiany wielkości 1-2 mm. Obserwacje przeprowadzone przez autorów badań skriningowych wykazały, że obecność cienia okrągłego płuca stwierdza się w ok. 20-51\% badanej populacji, a większość zmian jest mniej- szych niż $1 \mathrm{~cm}[13,14]$. Istnieją różne poglądy na temat postępowania w tej grupie pacjentów. Henschke i wsp. dowiedli, że dla zmian mniejszych niż $5 \mathrm{~mm}$ odpowiednim postępowaniem jest wykonanie kontrolnego badania tomograficznego po roku, a postępowanie bardziej agresywne nie jest efektywniejsze nawet w grupie podwyższonego ryzyka [15]. Wykrycie zmiany powyżej $1 \mathrm{~cm}$ wymaga wdrożenia dalszego postępowania diagnostyczno-terapeutycznego. Około 42-92\% zmian bez obecności zwapnień poniżej $1 \mathrm{~cm}$ to zmiany łagodne [4]. W analizie Hirai i wsp. wśród usuniętych zmian wielkości poniżej 1,5 cm stwierdzono obecność zmian złośliwych w $67 \%$ przypadków, a wśród zmian wielkości 2,1-2,5 cm - w 80\% przypadków [16]. Ray i wsp. pokazali, że średnia wielkość pojedynczego cienia okrągłego płuca dla zmiany złośliwej wynosiła $1,8 \mathrm{~cm}$ i była o 0,2 cm większa niż średnia wielkość wyliczona dla resekowanej zmiany niezależnie od etiologii [10]. W badaniach własnych wielkość zmiany o charakterze złośliwym oceniana w badaniu histologicznym była średnio o 0,1 cm większa niż szacowana na podstawie obrazów tomografii komputerowej.

Analiza zebranego materiału pozwoliła również na odnalezienie istotnej statystycznie zależności między lokalizacją pojedynczego cienia okrągłego płuca a charakterem zmiany. Wyniki te są zgodne z wynikami innych autorów. W analizie Raya 17 z 27 (63\%) zmian o charakterze złośliwym zlokalizowanych było w płatach górnych płuc [10]. W odróżnieniu od dostępnej literatury nie stwierdzono istotnej statystycznie zależności pomiędzy obecnością spikuli w TK klatki piersiowej a występowaniem nowotworu złośliwego [4].

W grupie 26 chorych ze zmianą łagodną najczęściej stwierdzano obecność odpryskowiaka (hamartoma). Jest on najczęstszym nowotworem łagodnym wśród pojedynczych cieni okrągłych płuc. W pracy Varoli i wsp. stwierdzono obecność 59 przypadków odpryskowiaka pośród 138 resekowanych zmian łagodnych, w innych pracach odsetek ten jest niższy - 2-14\% wszystkich PCOP [17]. Wśród zmian łagodnych wykrytych w badaniach własnych na szczególną uwagę zasługuje solitary fibrous tumour. Zmiana ta jest zaliczana do łagodnych pomimo tendencji do występowania miejscowej wznowy. W zebranej literaturze nie ma wzmianki o solitary fibrous tumour jako przyczynie obecności pojedynczego cienia okrągłego płuca.

Pośród 24 chorych ze zmianą złośliwą w 21 przypadkach był to nowotwór pierwotny płuca, w 3 pozostałych zmiana przerzutowa. Najczęściej rozpoznawanym typem histologicznym raka płuca był rak płaskonabłonkowy - 50\% pacjentów z nowotworem złośliwym i $24 \%$ wszystkich badanych, drugim w kolejności był natomiast gruczolakorak - 33 pacjentów z nowotworem złośliwym i 16\% wszystkich badanych. W dostępnej literaturze dominującym nowotworem wśród pojedynczych cieni okrągłych płuc będących pierwotną zmianą złośliwą jest gruczolakorak. W materiale Funakoshi i wsp. stwierdzono ten typ histologiczny zmiany u 38 z 43 pacjentów ze zmianą złośliwą, podczas gdy raka płaskonabłonkowego u jednego chorego [18]. Dodatni wywiad w kierunku chorób nowotworowych zwiększa ryzyko obecności zmiany złośliwej [4]. Ginsberg i wsp. w przedstawionej analizie pacjentów z PCOP stwierdzili występo- 
wanie zmiany o charakterze złośliwym u 59\% pacjentów w grupie chorych z dodatnim wywiadem w kierunku chorób nowotworowych, podczas gdy w grupie pacjentów bez takiego wywiadu odsetek ten wynosił 44\% [19]. Jednocześnie Quint i wsp. wykazali, że u większości pacjentów z dodatnim wywiadem nowotworowym i pojedynczym cieniem okrągłym płuca stwierdza się obecność pierwotnego raka płuca. Jednocześnie prawdopodobieństwo wystąpienia raka płuca zależy od histologicznego typu zmiany pozapłucnej [20].

W badanej grupie pacjentów nie wykazano istotnych statystycznie różnic w częstości i rodzaju występowania objawów. W grupie ze zmianą łagodną u 19 (73,08\%), a wśród chorych ze zmianą złośliwą u 17 (70,83\%) nie występowały żadne dolegliwości, a sam PCOP wykrywany był niejako przypadkowo. Obserwacje te są zgodne z danymi z dostępnej literatury. W odróżnieniu od danych z literatury nie stwierdzono związku występowania zmiany o charakterze złośliwym z nikotynizmem [11, 13].

Analiza wybranych parametrów badań laboratoryjnych również nie wykazała istotnych różnic w ich poziomie w obu grupach. Zarówno w grupie chorych ze zmianą złośliwą, jak i w grupie chorych ze zmianą łagodną większość ocenianych parametrów była w granicach normy. Nie stwierdzono istotnych statystycznie różnic w poziomie LDH, fibrynogenu, OB oraz markerów nowotworowych: SCC, NSE, Ca 19-9, Ca 15-3, CEA i Cyfra 21-1. Wydaje się więc, że parametry te nie są przydatne w różnicowaniu PCOP. Uzyskane wyniki potwierdzają dane z dostępnej literatury. Autorzy są zgodni, że podwyższone poziomy markerów nowotworowych lepiej różnicują pacjentów w bardziej zaawansowanych stadiach choroby nowotworowej i są bardziej przydatne w monitorowaniu niż wykrywaniu schorzenia [21-27].

Każda z metod wykorzystywanych w diagnostyce PCOP charakteryzuje się określoną czułością i swoistością. Żadna, poza badaniem histologicznym materiału pooperacyjnego, nie osiąga 100\%. Dlatego też istnieją prace dotyczące zwiększenia skuteczności różnicowania PCOP poprzez łączenie kilku metod. Gould i wsp. w swojej analizie wykazali, że wybór odpowiedniego postępowania zależy od oceny ryzyka wystąpienia nowotworu złośliwego. Na ryzyko to mają wpływ takie czynniki, jak wiek, nikotynizm, dodatni wywiad w kierunku chorób nowotworowych, wielkość pojedynczego cienia okrągłego, lokalizacja zmiany. Zaproponowali oni następujący schemat postępowania:

- wykonanie PET, gdy:

- ryzyko nowotworu złośliwego małe, w badaniu TK cechy zmiany złośliwej,

- ryzyko duże, w TK cechy zmiany łagodnej,

- ryzyko zabiegu chirurgicznego duże, ryzyko nowotworu złośliwego małe lub pośrednie, w badaniu TK cechy zmiany złośliwej,

- w TK cechy zmiany łagodnej, wysokie ryzyko niediagnostycznego wyniku biopsji transtorakalnej, pacjent nie wyraża zgody na obserwację zmiany;

- obserwacja zmiany, gdy:

- w TK klatki piersiowej zmiana < 10 mm,

- ryzyko zmiany nowotworowej bardzo niskie lub niskie i wynik PET negatywny,
- ryzyko zmiany nowotworowej bardzo niskie, w TK cechy zmiany łagodnej,

- w TK cechy zmiany łagodnej, niediagnostyczny wynik biopsji transtorakalnej a wynik PET negatywny;

- wykonanie biopsji transtorakalnej, gdy:

- wynik PET pozytywny i duże ryzyko zabiegu chirurgicznego lub brak zgody na zabieg,

- ryzyko zmiany nowotworowej niskie i wynik PET negatywny,

- ryzyko zmiany nowotworowej pośrednie i w TK cechy zmiany łagodnej;

- interwencja chirurgiczna, gdy:

- ryzyko zmiany nowotworowej jest wysokie i w TK zmiana nieokreślona lub ma cechy zmiany złośliwej,

- wynik PET pozytywny,

- ryzyko wystąpienia zmiany nowotworowej jest bardzo wysokie [28].

Diagnostyka PCOP jest problemem złożonym. Dostępność wielu metod, z których każda ma swoje ograniczenia, powoduje istnienie różnic w podejściu do diagnostyki wykrytej zmiany. Różnice te zależne są od charakterystyki pojedynczego pacjenta, a także - jak wykazały badania przeprowadzone w Austrii przez Proscha i wsp. - podejścia lekarza. Pulmonolodzy i torakochirurdzy częściej proponują bardziej inwazyjną diagnostykę niż radiolodzy, którzy częściej proponują obserwację zmiany [29].

\section{Wnioski}

1. U chorych z PCOP istnieje zależność pomiędzy wiekiem chorego ( $\geq 56,5$ roku) a ryzykiem obecności zmiany złośliwej.

2. Wśród pacjentów z PCOP istnieje zależność pomiędzy wielkością w badaniu tomografii klatki piersiowej w oknie płucnym $(\geq 1,45 \mathrm{~cm})$ a ryzykiem obecności zmiany złośliwej.

3. Wśród pacjentów z PCOP istnieje zależność pomiędzy lokalizacją zmiany (płat górny płuca prawego) a ryzykiem zmiany złośliwej.

4. Ocena stężenia LDH, fibrynogenu, wybranych markerów nowotworowych: SCC, NSE, Ca 19-9, Ca 15-3, CEA i Cyfra 21-1, oraz OB nie różnicuje PCOP.

\section{Piśmiennictwo}

1. Gurney J. Determining the likelihood of malignancy in solitary pulmonary nodules with bayesian analysis. Part I. Theory. Radiology 1993; 186: 405-13.

2. Liptay M. Solitary pulmonary nodule. Treatment options. Chest 1999; 116: 517S-518S.

3. Ooi G, Khong P, Yau Y. Advances in imaging of the solitary pulmonary nodule. Hong Kong Med I 2004; 10: 107-16.

4. Winer-Muram H. The solitary pulmonary nodule. Radiology 2006; 239: 34-49.

5. Blum J, Handmaker H, Rinne N. The utility of a somatostatin-type receptor binding peptide radiopharmaceutical (P829) in the evaluation of solitary pulmonary nodules. Chest 1999; 115: 224-32.

6. Erasmus JJ, Connolly JE, McAdams HP, Roggli VL. Solitary pulmonary nodules: Part I. Morphologic evaluation for differentiation of benign and malignant lesions. Radiographics 2000; 20: 43-58.

7. Graziano S, Tatum A, Newman N, et al. The prognostic significance of neuroendocrine markers and carcinoembryonic antigen in patients with resected stage I and II non-small cell lung cancer. Cancer Res 1994; 54: 2098-913. 
8. Garg K, Keith RL, Byers T, Kelly K, Kerzner AL, Lynch DA, Miller YE. Randomized controlled trial with low-dose spiral CT for lung cancer screening: feasibility study and preliminary results. Radiology 2002; 225: 506-10.

9. Baldwin D, Eaton T, Kolbe J, et al. Management of solitary pulmonary nodules: how do thoracic computed tomography and guided fine needle biopsy influence clinical decisions? Thorax 2002; 57: 817-22.

10. Ray JF 3rd, Lawton BR, Magnin GE, et al. The coin lesion story: update 1976. Twenty years' experience with thoracotomy for 179 suspected malignant coin lesions. Chest 1976; 70: 332-6.

11. Libby D, Smith J, Altorki N, Pasmantier M, Yankelevitz D, Henschke C. Managing the small pulmonary nodule discovered by CT. Chest 2004; 125: 1522-9.

12. Rubins J, Robins H. Temporal trends in the prevalence of malignancy in resected solitary pulmonary lesions. Chest 1996; 109: 100-3.

13. MacMahon H, Austin J, Gamsu G, Herold C, Jett J, Naidich D, Patz E, Swensen S. Guidelines for management of small pulmonary nodules detected on CT scans: a statement from the Fleischner Society. Radiology 2005; 237: 395-400.

14. Welker J, Alattar M, Gautam S. Repeat needle biopsies combined with clinical observation are safe and accurate in the management of a solitary pulmonary nodule. Cancer 2005; 103: 599-607.

15. Henschke C, Yankelevitz D, Naidich D, et al. CT screening for lung cancer: suspiciousness of nodules according to size on baseline scans. Radiology 2004; 231: 164-8.

16. Hirai S, Hamanaka Y, Mitsui N, Morifuji K, Uegami S. Role of videoassisted thoracic surgery for the diagnosis of indeterminate pulmonary nodule. Ann Thorac Cardiovasc Surg 2006; 12: 388-92.

17. Varoli F, Vergani C, Caminiti R, Francese M, Gerosa C, Bongini M, Roviaro G. Management of solitary pulmonary nodule. Eur J Cardiothorac Surg 2008; 33: 461-5.

18. Funakoshi Y, Sawabata N, Takeda S, Okumara Y, Hayakawa M, Maeda H. Bronchoscopically undiagnosed small peripheral lung tumors. Interact Cardiovasc Thorac Surg 2003; 2: 517-20.

19. Ginsberg M, Griff S, Go B, Yoo H, Schwartz L, Panicek D. Pulmonary nodules resected at video-assisted thoracoscopic surgery: etiology in 426 patients. Radiology 1999; 213: 277-82.

20. Quint L, Park C, lannettoni M. Solitary pulmonary nodules in patients with extrapulmonary neoplasms. Radiology 2000; 217: 257-61.

21. Ferrigno D, Buccheri G, Ricca I. Prognostic significance of blood coagulation tests in lung cancer. Eur Respir J 2001; 17: 667-73.

22. Rotenberg Z, Weinberger I, Sagie A, Fucha J, Davidson E, Sperling O, Agmon J. Total lactate dehydrogenase and its isoenzymes in serum of patients with non-small-cell lung cancer. Clin Chem 1988; 34: 668-70.

23. Nonaka M, Kataoka D, Yamamoto S, Bito A, Matsuoka J, Kawada T, Takaba T. Pre- and post-operative serum carcinoembryonic antigen in primary lung adenocarcinoma. Ann Thorac Cardiovasc Surg 2004; 10: 281-4.

24. Akoun GM, Scarna HM, Milleron BJ, Bénichou MP, Herman DP. Serum neuron-specific enolase. A marker for disease extent and response to therapy for small-cell lung cancer. Chest 1985; 87: 39-44.

25. Sánchez De Cos J, Masa F, de la Cruz JL, Disdier C, Vergara C. Squamous cell carcinoma antigen (SCC Ag) in the diagnosis and prognosis of lung cancer. Chest 1994; 105: 773-6.

26. Vollmer RT, Govindan R, Graziano SL, Gamble G, Garst J, Kelley MJ, Christenson RH. Serum CYFRA 21-1 in advanced stage non-small cell lung cancer: an early measure of response. Clin Cancer Res 2003; 9: 1728-33.

27. Niklinski J, Furman M, Chyczewska E, Chyczewski L, Rogowski F, Laudanski J. Diagnostic and prognostic value of the new tumour marker CYFRA 21-1 in patients with squamous cell lung cancer. Eur Respir J 1995; 8: 291-4.

28. Gould M, Sanders G, Barnett P, Rydzak C, Maclean C, McClellan M, Owens D. Cost-effectiveness of alternative management strategies for patients with solitary pulmonary nodules. Ann Intern Med 2003; 138: 724-35.

29. Prosch H, Strasser G, Oschatz E, Schober E, Schneider B, Mostbeck G. Management of patients with small pulmonary nodules: a survey of radiologists, pulmonologists, and thoracic surgeons. AJR 2006; 187: 143-8.

\section{Adres do korespondencji}

\section{Aleksandra Szlachcińska}

Oddział Kliniczny Chirurgii Klatki Piersiowej i Rehabilitacji Oddechowej WSS im. M. Kopernika w Łodzi

ul. Pabianicka 62

93-513 Łódź

tel. +48426895230

witaszczyk@hotmail.com 